\title{
PENGARUH SIKAP NASIONALISME PEMUDA TERHADAP KEAMANAN DI KOTA BANDUNG (STUDI PADA SISWA SMUN 3 DAN SMUN 5 BANDUNG)
}

\author{
Mochammad Nurdi Iriansyah ${ }^{1 *}$, Widya Setiabudi Sumadinata ${ }^{2}$, Yusa Djuyandi ${ }^{3}$ \\ ${ }^{1}$ Studi Keamanan, Universitas Padjadjaran, Bandung, Indonesia \\ ${ }^{2}$ Hubungan Internasional, Universitas Padjadjaran, Bandung, Indonesia \\ ${ }^{3}$ Ilmu Politik, Universitas Padjadjaran, Bandung, Indonesia \\ *Email: nurdi2007@yahoo.co.id
}

\begin{abstract}
Indonesia is an archipelagic country, of course, with the many islands owned by the Indonesian people, Indonesia is rich in natural resources and also rich in ethnic, religious and cultural diversity. Wealth, in turn, has an impact on the emergence of threats in people's lives in the form of conflicts and if this continues, it is one of the signs that Indonesian nationalism, especially in Bandung, is experiencing a threat and of course it will have an impact on security. This study uses an attitude theory approach, nationalism theory and security. This research method is quantitative with a questionnaire measuring instrument that is prepared based on research indicators sourced from research variables. The data analysis used simple linear regression analysis with the result that there was an influence of youth nationalism attitudes towards security with a contribution of $44 \%$. From these results it can be concluded that there is indeed an effect of nationalism on security where the lower the attitude of nationalism, the lower the security in the city of Bandung, and vice versa.
\end{abstract}

Keywords: Attitude, Nationalism, Youth, Security.

\begin{abstract}
Abstrak
Indonesia merupakan negara kepulauan, sudah tentu dengan banyaknya pulau-pulau yang dimiliki bangsa Indonesia tersebut, Indonesia menjadi kaya akan sumber-sumber kekayaan alam dan juga kaya akan keragaman suku, agama, dan budaya. Kekayaan, tersebut selanjutnya memberi dampak pada timbulnya ancaman di dalam kehidupan masyarakat berupa konflik dan jika hal itu terus terjadi, menjadi salah satu pertanda kalau nasionalisme Indonesia khususnya di Kota Bandung tengah mengalami ancaman dan sudah tentu akan memberi pengaruh terhadap keamanan. Penelitian ini menggunakan pendekatan teori sikap, teori nasionalisme dan keamanan. Metode penelitian ini bersifat kuantitatif dengan alat ukur angket yang disusun berdasarkan indikator penelitian bersumber dari variabel penelitian. Analisis data menggunakan analisis regresi linier sederhana dengan hasil Terdapat pengaruh sikap nasionalsime pemuda terhadap keamanan dengan sumbangan pengaruh sebesar $44 \%$. Dari hasil tersebut dapat ditarik kesimpulan bahwa memang ada pengaruh sikap nasionalisme terhadap keamanan dimana semakin rendah sikap nasionalisme, maka akan semakin rendah keamanan di kota Bandung, demikian pula sebaliknya.
\end{abstract}

Kata Kunci: Sikap, Nasionalisme, Pemuda, Keamanan. 


\section{PENDAHULUAN}

Undang-Undang Dasar 1945 (Pasal 25A) menyatakan, bahwa Negara Kesatuan Republik Indonesia adalah sebuah negara kepulauan yang berciri Nusantara; dengan wilayah yang batasbatas dan hak-haknya ditetapkan dengan undang-undang. Sebagai negara kepulauan Indonesia mempunyai lima pulau besar (Jawa, Sumatera, Kalimantan, Sulawesi, serta Papua) dan juga pulau-pulau sedang dan kecil lainnya. Sudah tentu dengan banyaknya pulau-pulau yang dimiliki bangsa Indonesia tersebut, Indonesia menjadi kaya akan sumber-sumber kekayaan alam dan juga kaya akan keragaman suku, agama, dan budaya. Keragaman suku, agama, dan budaya tersebut menjadi kekayaan tersendiri dalam bidang sosial budaya bangsa Indonesia yang kemudian melahirkan nilai-nilai seperti nilai-nilai kebersamaan, nilainilai kesamaan cita-cita serta solidaritas yang tinggi. Meski semua itu menjadi kekayaan, hal tersebut juga menjadi salah satu potensi terhadap timbulnya pemasalahan (konflik) di dalam kehidupan masyarakat, sehingga semua itu perlu dijaga dan dicarikan solusi yang terbaik dalam penanganannya jika terjadi konflik, agar tidak menyebabkan disintegrasi bangsa. Jika hal itu terjadi, maka itu pertanda kalau nasionalisme bangsa tengah mengalami ancaman.

Nasionalisme oleh Soekarno pada tahun 1926 dirumuskan sebagai itikad atau kemauan serta keinsyafan rakyat atau kesadaran rakyat Indonesia yang terdiri dari berbagai suku, agama, dan budaya untuk melebur menjadi satu golongan dan satu bangsa bangsa, yaitu bangsa Indonesia (Biliu, 2017). Karenanya nasionalisme itu kemudian membangkitkan suatu rasa percaya pada diri sendiri (sebagai bangsa Indonesia), yang diperlukan untuk mempertahankan diri di dalam perjuangan menghadapi berbagai ancaman dan tantangan yang bertujuan melemahkan bangsa Indonesia. Namun demikian sikap nasionalisme bangsa Indonesia tersebut saat ini di Kota Bandung tengah mengalami penurunan, terutama di kalangan generasi muda yang duduk di bangku sekolah. Misalnya di Batam (Wiyoga, 2019) dan di Malang (Rinaldi, 2020) terdapat siswa yang terancam dikeluarkan dari sekolah karena menolak untuk melakukan sikap hormat bendera saat upacara.

Lalu kejadian di tahun 2017 lalu tepatnya pada hari Senin, tanggal 21 Agustus 2017 sekitar pukul 15.30 dimana dua siswa SMUN 5 Bandung terluka karena diserang oleh puluhan pelajar (Sindonews, 2017), kemudian pada kejadian di hari Senin pada tanggal 3 Desember 2018 dua kelompok geng motor terlibat tawuran di jalan Jenderal Amir Machmud-Kebon Kopi RT 1 RW 6 Kelurahan Cibereum yang memakan korban dua orang mengalami luka dan harus mendapatkan penanganan medis serius (Pikiran Rakyat, 2018). Dan yang terbaru adalah kejadian pada tanggal 16 Agustus 2019 lalu dimana terjadi keributan antara pelajar SMAN 10 dan SMKN 2 Bandung (Ramadhan, 2019) yang lokasinya saling berdekatan.

Kejadian-kejadian tersebut sudah tentu menimbulkan kekhawatiran bagi warga masyarakat dan menjadikan mereka menilai kalau keamanan di Kota Bandung dan Indonesia pada umumnya saat ini cenderung kurang aman, hal ini seperti yang terlansir dalam survey Forbes dimana dikatakan jika Indonesia menjadi salah satu negara berbahaya di dunia (Babe.topbuzz, 2019). Kondisi tersebut sudah tentu sangat tidak menguntungkan, karenanya keamanan di Kota Bandung kini dan di masa depan sangatlah ditentukan oleh para pemudanya, karena mereka merupakan generasi penerus bangsa. Keamanan di 
Kota Bandung akan berada dalam kondisi yang bertambah lemah jika sikap nasionalisme pemuda terus mengalami penurunan. Untuk itu dalam upaya menciptakan kedamaian yang merupakan bagian dari keamanan diperlukan sikap mawas ke dalam melalui penguatan sikap nasionalisme pemuda yang diantaranya berupa rasa cinta tanah air, dan cinta sebagai sesama anak bangsa.

Dengan dapat terciptanya selalu semua itu, maka sikap nasionalisme akan menjadi kuat sebagimana Negera Korea Selatan yang di tahun 1970-an melalui Presidennya saat itu Park Chung Hee berhasil menguatkan semangat nasionalisme warga negaranya melalui gerakan Saemaul Undong, yaitu gerakan pembangunan masyarakat, dimana kunci sukses dari gerakan ini adalah adanya penguatan dukungan dan intervensi dari pemerintah terkait penyediaan layanan serta menanamkan semangat kemandirian dan persatuan (Warta Ekonomi, 2013).

Penelitian mengenai pengaruh sikap nasionalisme pemuda terhadap keamanan di Kota Bandung sepanjang pengetahuan peneliti belum pernah dilakukan. Namun, penelitian yang membahas mengenai nasionalisme pernah dibahas oleh beberapa peneliti terdahulu demikian pula dengan pembahasan mengenai ketahanan nasional. Rahayu (2009) melalui penelitian menemukan bahwa semakin tinggi nasionalisme mahasiswa akan semakin tinggi pula pergerakan mahasiswa; semakin tinggi perubahan sosial akan semakin tinggi pergerakan mahasiswa; dan semakin tinggi nasionalisme mahasiswa dan perubahan sosial akan semakin tinggi pergerakan mahasiswa. Maraliana (2012) menemukan bahwa respondennya mempunyai sikap nasionalisme yang tinggi dengan hasil sebanyak $(76,4 \%)$ pada responden yang memimiliki kebiasaan menyanyikan lagu kebangsaan Indonesia Raya, maka hal tersebut dapat menumbuhkan sikap nasionalisme yang tinggi pada siswa. Temuan Mansyah (2017) menemukan bahwa kondisi sosial budaya masyarakat di perbatasan masih rendah, hal itu disebabkan oleh karena terbatasnya sarana dan prasarana yang dibutuhkan oleh masyarakat untuk meningkatkan kualits hidup mereka terutama sekolah dan rumah sakit, masyarakat juga sangat memegang teguh adat istiadat dan tradisi yang diwarisi oleh nenek moyangnya, dan mereka sangat patuh serta taat kepada kepala suku atau ketua adat. Agar masyarakat di perbatasan tetap nasionalis, kepada mereka diberikan pembekalan tentang bela negara, pembekalan bela negara ini bertujuan untuk menanamkan nilai-nilai bela negara sehingga setiap warga negara memiliki kesadaran dan mampu mengaktualisasikan dalam kehidupan bermasyarakat, berbangsa dan bernegara sesuai peran dan profesi warga negara, demi menjaga kedaulatan negara, keutuhan wilayah dan keselamatan segenap bangsa dari segala bentuk ancaman.

Beberapa penelitian terdahulu yang disebutkan di atas menunjukkan bahwa penelitian yang dilakukan oleh peneliti di sini berbeda dengan penelitian-penelitian sebelumnya. Untuk itu peneliti terus melanjutkan penelitian sesuai judul di atas mengingat ada perbedaan dengan penelitian yang dilakukan oleh para peneliti sebelumnya. Perbedaan penelitian yang dilakukan oleh peneliti dengan peneliti-peneliti sebelumnya adalah terletak pada obyek penelitian, dalam hal ini obyek penelitian disini adalah pada pemuda dan tempat 
penelitian yang berlokasi di Kotamadya Bandung, serta keterkaitannya dengan Keamanan.

\section{METODE PENELITIAN}

Jenis penelitian yang dilakukan dalam penelitian ini dilihat dari pendekatan analisisnya tergolong kedalam penelitian yang menggunkan metode kuantitatif, dan Populasi dalam penelitian ini adalah pemuda/pelajar kelas 12 SMUN 3 dan SMUN 5 yang berusia 16 sampai dengan usia 18 tahun. Penelitian ini menggunakan tekhnik penarikan sampel Random sampling dengan jumlah sampel 250 orang. Alasan mengapa dalam penelitian ini melakukan penarikan sampel, sebab jumlah populasi penelitian tergolong besar. Menurut Sugiyono (2012) dikatakan dalam suatu penelitian dapat dilakukan penarikan sampel, mengingat adanya pertimbangan waktu, tenaga dan biaya. Dan selanjutnya menurut Azwar (1998) dikatakan bahwa beberapa ahli menyarankan untuk pengambilan sampel sebaiknya $10 \%$ dari jumlah populasi, namun jika jumlah tersebut dinilai masih terlalu banyak maka dapat dikurangi. Namun demikian jumlah sampel dinyatakan layak (Sugiyono, 2012) jika jumlahnya antara 30 sampai dengan 500 (limaratus).

Metode pengumpulan data dalam penelitian ini menggunakan metode angket yang disusun oleh peneliti berdasarkan indikator variabel penelitian, dan analisis data menggunakan analisis regresi linier sederhana. Peneliti juga menggunakan rumus perhitungan besaran sampel yang ditulis oleh Bungin (2011) dalam buku berjudul Metodologi Penelitian Kuantitatif, adapun rumus yang dimaksudkan tersebut adalah sebagai berikut:

$$
\begin{aligned}
& \mathrm{n}=\frac{\mathrm{N}}{\mathrm{N}(\mathrm{d})^{2}+1} \\
& \mathrm{n}=\frac{670}{670(0,05)^{2}+1} \\
& \mathrm{n}=250,46 \\
& \mathrm{n}=251
\end{aligned}
$$

Keterangan :

$\mathrm{n}=$ Jumlah smpel yang dicari

$\mathrm{N}=$ Jumlah populasi

$\mathrm{d}=$ Nilai presisi $($ ditentukan $95 \%$ atau $=$ $0,05)$

Variabel-variabel dalam penelitian ini adalah:

1. Variabel bebas/independent variable $(\mathrm{X})$ : sikap nasionalisme pemuda

2. Variabel terikat/dependent variable $(\mathrm{Y})$ : keamanan.

Agar penelitian dapat berjalan sesuai yang diinginkan, maka perlu dibuat definisi operasional yang berguna dalam menentukan alat ukur. Definisi operasional adalah petunjuk pelaksanaan bagaimana mengukur variabel (Singarimbun dan Effendi, 1989). Definisi operasional sangat diperlukan dalam menentukan pemakaian alat penelitian untuk mengambil data yang dibutuhkan dalam penelitian, sehingga data yang diperoleh akan dapat sesuai dengan tujuan penelitian. Dalam penelitian ini definisi operasional yang digunakan adalah sikap nasionalisme pemuda yang didefiniskan sebagai perbuatan seseorang yang didasari dari hasil pemikiran dan perasaannya untuk selalu lebih mengedepankan ke Indonesiaan yang didalamnya meliputi rasa cinta tanah air, semangat rela berkorban untuk kepentingan yang lebih besar, bangga sebagai bangsa Indonesi, selalu menjaga persatuan dan kesatuan dalam kesehariannya serta selalu mendasarkan perbuatannya kepada norma-norma 
bangsa Indonesia. Variabel lain yaitu keamanan yang didefinisikan sebagai suatu kondisi yang dinamis, bebas dari berbagai macam bentuk ancaman, sehingga keutuhan wilayah negara dan keberlangsungan pembangunan nasional dapat tercapai.

\section{HASIL DAN PEMBAHASAN}

Penelitian ini sebelumya dilakukan anaslisi diawali dengan melakukan uji validitas data penelitian. Uji ini dilakukan dengan menggunakan analysis pearson correlation dimana jika total dari analisis menunjukkan $<0.01$ atau $<0.05$ maka data dinyatakan valid. Hasil Pengujian validitas data (bariavel $\mathrm{X}$ dan Y) dapat dilihat pada tabel 1 . Terlihat bahwa kedua variabel baik itu sikap nasionalisme pemuda dan keamanan semuanya memperoleh hasil/status valid, hal ini terlihat dari nilai signifikansi dari masing-masing variabel yang $\geq 0.30$.

Tabel 1. Uji Validitas Data

\begin{tabular}{lllll}
\hline No & Variabel & Pearson Correlation & Signifikansi & Status \\
\hline 1 & Sikap Nasionalisme & $0.390-0.745$ & $\geq 0.30$ & Valid \\
& Pemuda & & & \\
\hline 2 & Keamanan & $0.402-0.722$ & $\geq 0.30$ & Valid \\
\hline
\end{tabular}

Sumber : Hasil penelitian, 2019.

Setelah dilakukan uji validitas selanjutnya dilakukan uji reliabilitas atau keterandalan. uji ini merupakan uji untuk mengetahui kekonsistenan dari alat ukur dalam arti, jika ia dilakukan kembali untuk mengukur maka hasil yang diperoleh tidak akan terlalu berbeda jauh, karena itu reliabilitas sering disebut juga dengan keajegan atau keterpercayaan. Dalam suatu penelitian reliabilitas ini dapat dilihat dari hasil uji statistic yaitu pada nilai Cronbach Alpaha $(\alpha)$ yang dihasilkan. Alat ukur dikatakan reliabel jika nilai Cronbach Alpaha $(\alpha) \geq 0,70$ dan jika nilai Cronbach Alpaha $(\alpha)<0,70$ maka dinyatakan tidak reliabel, dari hasil disini diperoleh nilai Cronbach Alpaha $(\alpha)$ untuk variabel sikap nasioanlisme pemuda sebesar 0.937 artinya bahwa alat ukur disini dinyatakan reliabel. Dan selanjutnya untuk variabel keamanan diperoleh nilai Cronbach Alpaha $(\alpha)$ sebesar 0.922 yang artinya alat ukur disini reliabel.

Setelah kedua uji ditas dilakukan selanjutnya dilakukan uji hipotesis yang dalam penelitian ini menggunakan analisis regresi linier sederhana, dikatakan demikian sebab hanya terdiri dari satu variebel independen dan satu variabel dependen. Hasil pengujian tersebut dapat dilihat tabel 2. Dari hasil uji hipotesis diperoleh $(\mathrm{R})=0.644$, artinya bahwa terdapat hubungan antara sikap nasionalisme pemuda dengan keamanan dengan arah positif dan derajad sedang. Dan pada kolom $\mathrm{R}$ Square diperoleh nilai $=0.441$. Angka ini mengartikan bahwa variabel independent (X) sikap nasionalisme pemuda memberi pengaruh terhadap variabel dependen (Y) keamanan sebesar $44 \%$ sedangkan sisanya $56 \%$ dipengaruhi oleh variabel lain diluar penelitian. Variabel lain ini menjadi penunjuk bahwa untuk menciptakan keamanan di Kota Bandung tidak hanya cukup dengan meningkatkan sikap nasionalisme pemuda belaka akan tetapi ada variabel lain yang perlu dilibatkan seperti agama, adat istiadat yang berupa silih asih, silih asah dan asuh serta lain sebagainya. 
Tabel 2. Model Summary

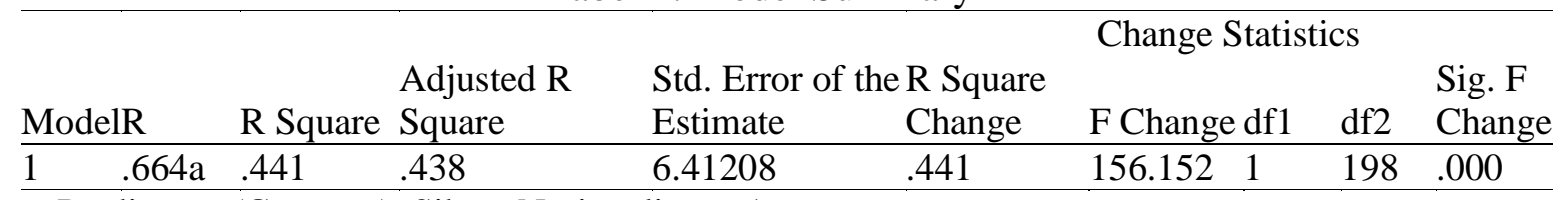

a. Predictors: (Constant), Sikap_Nasionalisme_1

Sumber: Hasil penelitian, 2019.

Berikutnya dari tabel 3 Anova, diperoleh hasil nilai Fhitung $=156.152$ dengan tingkat signifikansi < probabilitas $(0.00<0.05)$ dengan demikian dapat ditarik kesimpulan dari hal ini bahwa $\mathrm{H} 0$ yang menyatakan tidak terdapat pengaruh sikap

nasionalisme pemuda terhadap keamanan di Kota Bandung ditolak dan H1 yang menyatakan terdapat terdapat pengaruh sikap nasionalisme pemuda terhadap keamanan di Kota Bandung, diterima.

Tabel 3. Anova

\begin{tabular}{|c|c|c|c|c|c|c|}
\hline \multicolumn{2}{|l|}{ Model } & \multicolumn{2}{|c|}{ Sum of Squares df } & \multirow{2}{*}{$\begin{array}{l}\text { Mean Square } \\
6420.164\end{array}$} & \multirow{2}{*}{$\begin{array}{l}\mathrm{F} \\
156.152 \\
\end{array}$} & \multirow{2}{*}{$\begin{array}{l}\text { Sig. } \\
.000 \mathrm{~b}\end{array}$} \\
\hline 1 & Regression & 6420.164 & 1 & & & \\
\hline & Residual & 8140.716 & 198 & 41.115 & & \\
\hline & Total & 14560.880 & 199 & & & \\
\hline
\end{tabular}

a. Dependent Variable: Keamanan

b. Predictors: (Constant), Sikap Nasionalisme Pemuda

Sumber: Hasil penelitian, 2019.

Selanjutnya dari tabel 4 diperoleh nilai constant $=33.036$ (keamanan) dan Sikap nasionalisme 0.542 (b), sehingga dari rumus persamaan regresi $\mathrm{Y}=\mathrm{a}+\mathrm{b}$ $\mathrm{x}$ maka dapat dibuat rumus persamaan regresinya menjadi $\mathrm{Y}=33.036+0.542$ $\mathrm{X}$ dari persamaan rumus tersebut menunjukkan bahwa terdapat hubungan positif anatar variabel $\mathrm{X}$ dengan variabel $Y$. Terjadinya peningkatan pada sikap nasionalisme pemuda sebesar 1 satuan, akan berpengaruh pada peningkatan keamanan sebesar 33.578 satuan. Hasil tersebut tercermin melalui jawaban responden seperti tercantum dalam tabel 5.

Tabel 4. Coefficientsa

\begin{tabular}{|c|c|c|c|c|c|}
\hline \multirow[b]{2}{*}{ Model } & \multicolumn{2}{|c|}{$\begin{array}{l}\text { Unstandardized } \\
\text { Coefficients }\end{array}$} & \multicolumn{3}{|c|}{$\begin{array}{l}\text { Standardized } \\
\text { Coefficients }\end{array}$} \\
\hline & B & Std. Error & Beta & $\mathrm{t}$ & Sig. \\
\hline (Constant) & 33.036 & 4.514 & & 7.318 & .000 \\
\hline $\begin{array}{l}\text { Sikap } \\
\text { Nasionalisr }\end{array}$ & .542 & .043 & .664 & 12.496 & .000 \\
\hline
\end{tabular}

Sumber: Hasil penelitian, 2019.

Jawaban responden berdasar pada masing-masing indikator angket sikap nasionalisme pemuda. 
Tabel 5. Distribusi Jawaban Respoden pada Variabel Sikap Nasionalisme Pemuda

\begin{tabular}{|c|c|c|c|c|c|c|c|c|c|c|c|}
\hline \multirow[t]{2}{*}{ No } & \multirow[t]{2}{*}{ Indikator } & \multicolumn{2}{|c|}{$\begin{array}{l}\text { Sangat } \\
\text { setuju }\end{array}$} & \multicolumn{2}{|c|}{ Setuju } & \multicolumn{2}{|c|}{$\begin{array}{l}\text { Cukup } \\
\text { setuju }\end{array}$} & \multicolumn{2}{|c|}{$\begin{array}{l}\text { Tidak } \\
\text { setuju }\end{array}$} & \multicolumn{2}{|c|}{$\begin{array}{c}\text { Sanga tidak } \\
\text { setuju }\end{array}$} \\
\hline & & Frek & $\%$ & Frek & $\%$ & Frek & $\%$ & Frek & $\%$ & Frek & $\%$ \\
\hline 1. & Cinta tanah air & 120 & $60 \%$ & 50 & $25 \%$ & 30 & $15 \%$ & - & - & - & - \\
\hline 2. & Rela berkorban & 100 & $50 \%$ & 60 & $30 \%$ & 40 & $20 \%$ & - & - & - & - \\
\hline 3. & $\begin{array}{l}\text { Menjaga persatuan } \\
\text { dan kesatuan }\end{array}$ & 60 & $30 \%$ & 100 & $50 \%$ & 40 & $20 \%$ & - & - & - & - \\
\hline 4. & $\begin{array}{l}\text { Norma bangsa } \\
\text { Indonesia }\end{array}$ & 50 & $25 \%$ & 120 & $60 \%$ & 30 & $15 \%$ & - & - & - & - \\
\hline
\end{tabular}

Sumber: Hasil penelitian, 2019.

Hasil pada tabel 5 menunjukkan bahwa pada umumnya pemuda di SMA 3 dan 5 Bandung memiliki rasa cinta tanah air, kecintaan ini ditunjukkan dalam berbagai cara seperti dengan jalan berusaha menjadi pribadi yang baik dalam bersikap di kesehariannya, berusaha mengaharumkan nama sekolah dengan belajar giat dan menghasilkan prestasi yang baik, mengenal secara geografi nama-nama pulau yang menjadi bagian dari NKRI, kebudayaan, suku dan bahasa. Selain itu juga mereka memiliki rasa rela berkorban. Mereka mau untuk mendahulukan kepentingan umum daripada kepentingan pribadi seperti saat kegiatan upacara bendera dalam memperingati hari nasional yang jatuh pada hari libur sekolah, pemudapemuda ini rela dan mau datang kesekolah untuk melaksanakan kegiatan upacara. Sikap seperti ini menunjukkan kalau pemuda SMAN 3 dan 5 memiliki rasa kebanggaan yang tinggi terhadap bangsanya.

Dalam hal persatuan dan kesatuan, pemuda-pemuda di SMAN 3 dan 5 juga memiliki kesadaran yang tinggi. Hal ini tercermin dari jawaban keseluruhan mereka yang pada umumnya setuju untuk menjaga persatuan dan kesatuan. Mereka memiliki kemauan kuat untuk saling menghargai adanya perbedaan pendapat diantara satu pemuda dengan pemuda lainnya sekalipun beda sekolah saat sedang berinteraksi, sekalipun diantara pemuda-pemuda SMA 3 dan 5 pernah beberapa kali mengalami benturan/konflik itu hanyalah dilakukan oleh sebagian kecil oknum pemuda saja, namun tidaklah mewakili keseluruhan pemuda di SMAN 3 dan 5 Bandung. Para pemuda selalu menumbuhkan semangat kebersamaan dengan jalan mau bersama melakukan aktivitas bersama seperti olahraga dan lain sebagainya, sekalipun diluar jam sekolah.

Selanjutnya dalam hal norma bangsa yang didalam hal ini meliputi kepatuhan terhadap peraturan, norma budaya masyarakat dan sejenisnya oleh pemuda dinyatakan setuju bahwa pemuda perlu lebih bisa mengendalikan tingkah lakunya yang bertentangan dengan norma masyarakat, perilaku yang bertentangan tersebut seperti perilaku tawuran yang terjadi beberapa waktu lalu di kedua SMU ini. Tawuran tersebut sesungguhnya merupakan contoh dari adanya pergeseran norma budaya yang selama ini berlaku. Mereka yang tawuran telah mengabaikan norma-norma tersebut dan hal itu terjadi oleh karena mereka telah terjebak dalam lingkaran dampak globalisasi yang lebih mengedepankan sikap tidak peduli pada orang lain (siswa SMU lain) yang mengarah pada sifat anarkisme.

Terkait dengan keamanan, sesungguhnya kemanan ini telah 
menjadi amanah dari para pendiri bangsa Indonesia. Dimana amanah tersebut jelas tertulis di dalam pembukaan undang-undang dasar 1945 "Kemudian daripada itu untuk membentuk suatu Pemerintahan Negara Indonesia yang melindungi segenap bangsa Indonesia dan seluruh tumpah darah Indonesia...." dari kalimat yang tertulis dalam pembukaan undangundang dasar 1945 tersebut jelas bahwa pemerintah berkewajiban melindungi segenap warganya dari segala bentuk ancaman, namun demikian pemerintah didalam menjalankan tugas kepemerintahannya memerlukan dukungan dan peran serta dari para warganya termasuk pemuda dalam usaha menciptakan keamanan bersama. Peran keamanan dari para pemuda disini dimulai dari keamanan dalam diri setiap pribadi sebagai warga negara yang diwujudkan dalam bentuk sikap saling menjaga diri untuk tidak mudah terpancing emosi amarah dan lain sebagainya.

Dalam keadaan amarah kontrol diri dalam diri individu akan cenderung mudah tidak terkontrol, sehingga perilakunya menjadi tidak terkendali dan cenderung bersifat destruktif atau merusak. Dan jika keadaan ini terjadi pada seseorang dan kemudian berlanjut dengan melibatkan orang lain dalam kelompok dengan jumlah yang tidak kecil, maka perilaku ini akan menjadi sebuah kekuatan besar yang mampu menimbulkan kerusakan terhadap obyek-obyek yang ada disekitarnya dan sudah tentu keadaan demikian akan menimbulkan ketakutan dan keresahan bagi orang lain disekitarnya.

Tabel 6. Distribusi Jawaban Respoden pada Variabel Keamanan

\begin{tabular}{|c|c|c|c|c|c|c|c|c|c|c|c|}
\hline \multirow[t]{2}{*}{ No } & \multirow[t]{2}{*}{ Indikator } & \multicolumn{2}{|c|}{$\begin{array}{l}\text { Sangat } \\
\text { setuju }\end{array}$} & \multicolumn{2}{|c|}{ Setuju } & \multicolumn{2}{|c|}{$\begin{array}{l}\text { Cukup } \\
\text { setuju }\end{array}$} & \multicolumn{2}{|c|}{$\begin{array}{l}\text { Tidak } \\
\text { setuju }\end{array}$} & \multicolumn{2}{|c|}{$\begin{array}{l}\text { Sanga tidak } \\
\text { setuju }\end{array}$} \\
\hline & & Frek & $\%$ & Frek & $\%$ & Frek & $\%$ & Frek & $\%$ & Frek & $\%$ \\
\hline 1. & $\begin{array}{l}\text { Bebas melakukan } \\
\text { aktivitas }\end{array}$ & 140 & $70 \%$ & 50 & $25 \%$ & 10 & $5 \%$ & - & - & - & - \\
\hline 2. & $\begin{array}{l}\text { Keutuhan wilayah } \\
\text { negara }\end{array}$ & 100 & $50 \%$ & 60 & $30 \%$ & 40 & $20 \%$ & - & - & - & - \\
\hline 3. & $\begin{array}{l}\text { Pembangunan } \\
\text { nasional }\end{array}$ & 140 & $70 \%$ & 40 & $20 \%$ & 20 & $10 \%$ & - & - & - & - \\
\hline
\end{tabular}

Sumber: Hasil penelitian, 2019.

Dengan kondisi lingkungan yang aman membuat pemuda dan orang lain bebas melakukan aktivitasnya dengan aman dan lancar. Situasi aman tersebut dapat terwujud karena adanya kepedulian diantara para pemuda dari kedua sekolah dalam usahanya menciptakan situasi yang aman. Dalam hal ini pemuda berpendapat bahwa keamanan ini hendaknya juga dapat diwujudkan dalam lingkup yang lebih besar seperti di kampung-kampung dan pemukiman penduduk lainnya. Dan sudah tentu harapan ini bertumpu pula pada peran dari aparat keamanan seperti dalam mengatasi demonstrasi massa yang terjadi di Kota Bandung beberapa waktu lalu dan menimbulkan keresahan bagi masyarakat pada umumnya.

Terkait dengan beberapa peristiwa yang terjadi belakangan ini dan memberi pengaruh pada situasi keamanan di Kota Bandung pada umumnya dan dilingkungan kedua sekolah ini pada kususnya, seperti perkelahian pelajar, perkelahain antar geng dan lain sebagainya. Secara umum 
pemuda di kedua sekolahan ini menyatakan bahwa karakter moral pemuda atau masyarakat yang demikian perlu untuk ditingkatkan karakter moralnya. Karena perkelahian antar pelajar dan sejenisnya hanya membuat orang lain disekitarnya terganggu keamanannya. Terganggunya keamanan orang lain ini tergolong dalam ancaman sositeal yang oleh Buzan (1991) digolongkan kedalam keamanan yang terganggu oleh sebab datangnya dari dalam negeri berupa perubahan nilainilai budaya, pengerusakan hak milik dan lain sebagainya.

Perkelahian antar pelajar ini oleh sebagian masyarakat masih ada yang dianggap sebagai bentuk dari kenakalan remaja biasa yang sedang mencari identitas diri, namun dalam konteks perkembangan kepribadian individu, hal ini tidak dapat dianggap remeh. Perkelahian ini terkait dengan keadaan moral individu, moral merupakan perangkat ide-ide tentang tingkah laku dengan warna dasar tertentu yang dipegang oleh seseorang dalam sekelompok manusia didalam lingkungan tertentu. Jika moral ini kemudian tidak terkendali, maka perilaku pun akan tidak terkendali dan dalam konteks yang lebih luas jika orang-orang dengan moral yang demikian terkumpul, dan terbaca oleh orang atau kelompok tertentu maka akan dengan mudah dipengaruhi serta dikendalikan oleh orang lain yang mempunyai kepentingan seperti dikendalikan untuk tujuan melakukan demonstrasi dan lain sebagainya yang dalam konteks luas hal itu dapat mempengaruhi kondisi keamanan suatu wilayah dan berdampak pula pada kemajuan pembangunan suatu wilayah.

\section{PENUTUP}

Dari data yang didapatkan dan pembahasan yang telah dilakukan pada penelitian ini, maka dapat ditarik kesimpulan bahwa Penelitian ini telah membuktikan adanya pengaruh sikap dan signifikansi antara variabel sikap nasionalisme pemuda terhadap keamanan. Dengan sifat diri yang lebih mengedepankan musyawarah didalam menghadapi persoalan, saling menghargai pendapat dan perbedaan dengan orang lain dapat menjadikan keamanan di Kota Bandung aman.

\section{DAFTAR PUSTAKA}

Azwar, S. (1998). Metode Penelitian. Yogyakarta: Pustaka Pelajar.

Babe Topbuzz. Indonesia Salah Satu Negara Bebrahaya di Dunia. Diakses pada babe.topbuzz.com 17/09/2019

Biliu, Y. (2017). Pemikiran Soekarno tentang Islamisme dan Pemahaman Pendidikan Islam. Jurnal Ilmiah AL-Jauhari, 2(2): 159-177.

Bungin, B. (2011). Metodologi Penelitian Kuantitatif (cetakan ke9). Depok: Prenamedia Group.

Buzan, B. (1991). People, States and Fears, An Agenda for International Security Studies in Post Cold War. Boulder: Lynne Rienner Publishers.

Mansyah, A. (2017). Nasionalisme Masyarakat Indonesia Di Perbatasan Dan Dampaknya Terhadap Kedaulatan Negara (Studi Di Kabupaten Sanggau, Kalimantan Barat). Jurnal Prodi Peperangan Asimetris, 3(3), Desember 2017.

Maraliana. (2012). Studi Kebiasaan Menyanyikan Lagu Kebangsaan Indonesia Raya Dan Sikap Nasionalisme Siswa Kelas XI SMAN 2 Yogyakarta. Journal Citizenship, (2) 1, Juli 2012. 
Pikiran Rakyat. (2018). Dua Pimpinan Geng Motor di Cipatat, Berduel Satu Diamankan Polisi. <https://www.pikiranrakyat.com> (4/12/2018)

Rahayu, M. (2009). Nasionalisme Mahasiswa dan Perubahan Sosial Terhadap Pergerakan Mahasiswa di Era Reformasi (Studi Kasus Di Universitas Indonesia). Jakarta: Universitas Indonesia.

Ramadhan, D. I. (29 Okt 2019). Kronologi Pelajar SMAN 10 dan SMKN 2 Kota Bandung Saling Serang. Detiknews. Diakses pada https://news.detik.com/beritajawa-barat/d-4764076/kronologipelajar-sman-10-dan-smkn-2kota-bandung-saling-serang

Rinaldi, I. (16 Juli 2020). Dimutasi karena Sikap Hormat Tak Bisa Diubah, Orangtua Murid Gugat ke PTUN. Kompas. Diakses pada https://kompas.id/baca/polhuk/202 0/07/16/ideologi-pancasilalembaga-negara-harus-pahamiberagam-ancaman/
Sindonews. (2017). 2 Siswa SMAN 5 Bandung Terluka Diserang Puluhan Pelajar.

$<$ https://sindonews.com> (22/08/2017)

Singarimbun, M., \& Effendi, S. (1989). Metode Penelitian Survai. Jakarta: LP3ES.

Sugiyono. (2012). Metode Penelitian Pendidikan. Pendekatan Kuantitatif, Kualitatif dan $R \& D$ (cetakan ke-17). Bandung: Alfabeta.

Warta Ekonomi. (18 November 2013). Saemaul Undong: Korea Membangun Mulai Dari Desa. Warta Ekonomi. Diakses pada https://www.wartaekonomi.co.id/r ead19922/saemaul-undong-koreamembangun-mulai-dari-desa

Wiyoga, P. (27 November 2019). Sikap Upacara Tak Bisa Diubah, Dua Siswa di Batam Terancam Dikeluarkan. Kompas. Diakses pada

https://kompas.id/baca/nusantara/ 2019/11/27/menolak-hormat-saatupacara-bendera-dua-siswa-dibatam-terancam-dikeluarkan/ 